\title{
BOUNDEDNESS OF THE MARCINKIEWICZ INTEGRAL ON GRAND VARIABLE HERZ SPACES
}

\section{Hammad Nafis, Humberto Rafeiro* and Muhammad Asad Zaighum}

Abstract. We prove the boundedness of the Marcinkiewicz integral on grand variable Herz spaces.

Mathematics subject classification (2020): 46E30.

Keywords and phrases: Herz spaces, Grand spaces, variable exponent spaces, Marcinkiewicz integral.

\section{REFERENCES}

[1] A. Almeida And D. Drinem, Maximal, potential and singular type operators on Herz spaces with variable exponents, J. Math. Anal. Appl., 394 (2): 781-795, 2012.

[2] D. Cruz-Uribe, A. Fiorenza, Variable Lebesgue Space, Foundations and Harmonic Analysis, Birkhäuser, 2013.

[3] D. Cruz-Uribe, A. Fiorenza, J. Martell and C. Pérez, The boundedness of classical operators on variable $L^{p}$ spaces, Ann. Acad. Sci. Fenn. Math., 31 (1): 239-264, 2006.

[4] L. Diening, P. Harjulehto, Hästö, And M. RuZicka, Lebesgue and Sobolev Spaces with variable exponents, Springer-Verlag, Lecture Notes in Mathematics, vol. 2017, Berlin, 2011.

[5] H. G. Feichtinger And F. Weisz, Herz spaces and summability of Fourier transforms, Math. Nachr., 281 (3): 309-324, 2008.

[6] A. FiorenZA, B. GuptA AND P. JAin, The maximal theorem for weighted grand Lebesgue spaces, Studia Math., 188, no. 2, 123-133, 2008.

[7] L. GRAFAKOS, X. LI, AND D. YANG, Bilinear operators on Herz-type Hardy spaces, Trans. Amer: Math. Soc., 350 (3): 1249-1275, 1998.

[8] L. GReCo, T. IWANIEC AND C. SBORdOnE, Inverting the p-harmonic operator, Manuscripta Math., 92, no. 2, 249-258, 1997.

[9] E. HERNANDEZ AND D. YANG, Interpolation of Herz spaces and application, Math. Nachr., 205 (1): 69283-87, 1999.

[10] C. HERZ, Lipschitz spaces and Bernstein's theorem on absolutely convergent Fourier transform, J. Math. Mech., 18: 283-323, 1968/69.

[11] T. IWANIEC AND C. SBORDONE, On the integrability of the Jacobian under minimal hypotheses, Arch. Ration. Mech. Anal., 119, no. 2, 129-143, 1992.

[12] M. IZUKI, Boundedness of vector-valued sublinear operators on Herz-Morrey spaces with variable exponent, Math. Sci. Res. J., 13 (10): 243-253, 2009.

[13] M. IZUKI, Boundedness of sublinear operators on Herz spaces with variable exponent and application to wavelet characterization, Analysis Mathematica, 13 (36): 33-50, 2010.

[14] R. Johnson, Temperature, Riesz potenial and the Lipschitz spaces of Herz, Proc. London Math. Soc., 27 (2): 290-316, 1973.

[15] R. Johnson, Lipschitz spaces, Littlewood-Paley spaces and convoluteurs, Proc, London Math. Soc., 29 (1): 127-141, 1974.

[16] V. KoKILASHVILI, Boundedness criteria for singular integrals in weighted grand Lebesgue spaces, J. Math, Sci. (N. Y.), 170, no. 1, 20-33, 2010.

[17] V. KokilashVili And A. Mes Khi, A note on the boundedness of the Hilbert transform in weighted grand Lebesgue spaces, Georgian Math. J., 16, no. 3, 547-551, 2009. 
[18] V. KokilashVili And A. Meskhi, Trace inequalities for fractional integrals in grand Lebesgue spaces, Studia Math., 210, no. 2, 159-176, 2012.

[19] V. KokilashVili And A. Mesk Ki, Potentials with product kernels in grand Lebesgue spaces:Oneweight criteria, Lith. Math. J., 23, no. 1, 27-39, 2013.

[20] V. Kokilashvili and A. Meskhi, H. Rafeiro, S. Samko, Integral Operators in Non-Standard Function Spaces, Vol. 1, Oper. Theory Adv. Appl. 248, Birkhäuser, Cham, 2016.

[21] V. Kokilashvili and A. Meskhi, H. Rafeiro, S. Samko, Integral Operators in Non-Standard Function Spaces, Vol. 2, Oper. Theory Adv. Appl. 249, Birkhäuser, Cham, 2016.

[22] Y. Komori, Notes on singular integrals on some inhomogeneous Herz spaces, Taiwanese J. Math., 8 (3): 547-556, 2004.

[23] O. KavaciK And J. Rakosnik, On spaces $L^{p(x)}$ and $W^{k, P(x)}$, Czechoslovak Math. J., 41 (116): 592-618, 1991.

[24] A. Meskni, Weighted criteria for the Hardy transform under the $B_{p}$ condition in grand Lebesgue spaces and some application, J. Math. Sci. (N. Y), 178, no. 6, 622-636, 2011.

[25] A. MesKHI, Criteria for the boundedness of potential operators in grand Lebesgue spaces, Proc. A. Razmadeze Math. inst., 169, 119-132, 2015.

[26] A. Meskit, H. Rafeiro, And M. A. Zaighum, Central Calderon-Zygmund Operators On Herztype Hardy Spaces Of Variable Smoothness and Integrability, Ann. Funct. Anal., 2017.

[27] B. MucKenHoupt, R. L. WheEden, Weighted norm inequalities for singular and fractional integrals, Trans. Am. Maths. Soc. 249-258, 161 (1971).

[28] H. Nafis, H. Rafeiro, M. A. Zaighum, A note on the Boundedness of Sublinear Operators on Grand Variable Herz Spaces, J. Inequal. Appl., 2020, 1 (2020).

[29] V. D. Radulescu, D. RePoves, Partial differential equations with variable exponents: variational methods and qualitative analysis, 1st edition, Chapman and Hall/CRC, pub. June 24, 2015.

[30] H. RafeIro, AND S. S AmKo, Riesz potential operator in continual variable exponents Herz spaces, Math. Nach., 288 (4), 465-475, 2015.

[31] H. RAFeiro, S. SAmKo, AND S. UmarkhadZhiev, Grand Lebesgue sequence spaces, Georgian Math. J., 2018.

[32] M. RuZICKA, Electroreological Fluids: Modeling and Mathematical Theory, Springer, Lecture Notes in Math., vol. 1748, 176 pages, 2000.

[33] S. G. SAMKo, On a progress in the theory of Lebesgue spaces with Variable exponents: maximal and singular operators, Integr. Transf. and Spec. Funct., 16 (5-6): 461-482, 2005.

[34] S. G. S Aмко, Variable exponents Herz space, Mediterr. J. Math., 10 (4): 2007-2025, 2013.

[35] F. SORIA AND G. WeISS, A remark on singular integrals and power weights, Indiana University Mathematical Journal, vol. 43, no. 1, pp. 187-204, 1994.

[36] E. Stein, On the functions of Littlewood-Paley, Lusin, and Marcinkiewicz, Trans. Amer. Math. Soc., 88: 430-466, 1958.

[37] H. WANG, Commutators of Marcinkiewicz integrals on Herz spaces with variable exponent, Czechoslovak Mathematical Journal 66: 251-269, 2016. 